\title{
The Effect of Human Capital Development on Employees' Attitude to Work in Insurance Industry in Nigeria
}

\author{
Lanre Amodu ${ }^{1}$, Philip Alege $^{2}$, Stephen Oluwatobi $^{3}$ and Thelma Ekanem ${ }^{4}$ \\ 1,4 Department of Mass Communication, Covenant University \\ ${ }^{2,3}$ Department of Economics and Development Studies
}

Correspondence should be addressed to: Lanre Amodu; lanre.amodu@covenantuniversity.edu.ng

Received date: 6 March 2017; Accepted date: 14 June 2017; published date: 21 November 2017

Academic Editor: Samuel Kimnyak Partoip

Copyright (c) 2017. Lanre Amodu, Philip Alege, Stephen Oluwatobi and Thelma Ekanem. Distributed under Creative Commons CC-BY 4.0

\begin{abstract}
Evidence from the literature confirms that firms are as productive as the quality of their factors of production, which includes labour (workers). This suggests that the quality of workers in a firm, in terms of attitude to work, determines the productivity of that firm. Firms can, thus, improve their performances by investing in their workers in such a way that their workers' possess positive attitude to work. Such investments, which represent human capital development as well as employee relations, can be in the form of bonuses, salary upgrade, commendations and sponsored trainings, among others. The research questions that arise include: do firms recognise this factor as a way of improving productivity? To what extent do incentives improve firms' productivity? The objective of this study, therefore, is to examine the effect of human capital development on workers' attitude to work using Mutual Benefits Assurance Plc as a case. The study is founded on a theoretical foundation established by Human Capital Theory, and Correlation estimation technique was adopted for the research method. The findings revealed that the company engaged in human capital development which enhanced employees' attitude to work, though there was a high level of employee turn-over as they grew older. It was, therefore, recommended that the organisation should adopt measures to achieve human capital sustainability.
\end{abstract}

Keywords: Human Capital, Labour, employee relations, Investment, Firms

Cite this Article as: Lanre Amodu, Philip Alege, Stephen Oluwatobi and Thelma Ekanem (2017)," The Effect of Human Capital Development on Employees' Attitude to Work in Insurance Industry in Nigeria ", The Journal of Organizational Management Studies, Vol. 2017 (2017), Article ID 494914, DOI: 10.5171/2017.494914 


\section{Introduction}

Competition is a word most businesses are quite familiar with. Considering that several organizations provide similar products and services, and are targeting the same market, the chances of losing business to a competitor are high. From time to time, organizations evolve new strategies and approaches to ensure they emerge from multitude of choices as the preferred brand. Nevertheless, several organizations are still unable to cope with the dynamic taste of the modern day customers. Porter (1990) describes productivity as the only meaningful concept of competitiveness. This means that irrespective of the high level of competition, an organization must be productive if it will be considered as being competitive.

While discussing how small businesses can engage superior competitive advantage to master the art competition, Bressler (2014) advises that small businesses should not expect a warm and open arm welcome from the business community. Rather, they should be ready for resistance from businesses that would consider them a threat. The author further states that for there to be successful market penetration, sound strategy must be devised by the new businesses.

Globalization, in spite of its numerous opportunities, has also further complicated the issue of competition. This is because organizations no longer compete with local brands; rather, they compete with brands from across the globe. This means that every organization must be ready, not only to build its business to global standards, but also to seek to outperform global competition.

Dae-Bong (2009) also observes that with the advent of globalization came challenges such as knowledge-based economy and technological evolutions, which have forced organizations to seek new strategies for maintaining competitive advantage. The author further asserts that the prevailing sense on how to achieve success is to focus on people who possess higher levels of individual competence.

Bressler (2014) observes that though literature has considerably covered the significance of employees as relates to the competitiveness of a business, the employees are considered secondary to product, place, price and promotion. The author, however, argues that the employees play a pivotal role in synergizing the other elements. Consequently, failure on the part of the employees will automatically result in the failure of the other elements. With the consideration of the value of employees to any organization, this study examines how the development of human capital can affect the attitude of employees to their work. We focus on the insurance industry in Nigeria and select Mutual Benefit Assurance Ltd, one of the leading insurance companies in Nigeria, as a case.

\section{Statement of the Problem}

Several businesses are established daily, joining the pool of already existing ones. In the same vein, several businesses are closed down for failure to keep up with market requirements. According to Oduyoye, Adebola and Binuyo (2013, p.71), "Worldwide, there are about 300 million people trying to start about 150 million businesses; about one-third will be launched, so one can assume 50 million new firms births per year or about 137,000 per day". The authors, however, note that about 120,000 of that figure probably terminate business everyday worldwide. The survival of any business is determined, to a large extent, by its ability to satisfy its target market through constant innovation and elevation of service quality. It is, however, unfortunate that some organizations tend to drive productivity and customer satisfaction at the expense of their employees. They demand greater speed, initiative, efficiency and customer satisfaction without developing the capacity of the employees to 
meet up with the ever growing trends in the industry. The implication of this is that the employees tend to believe that the organization does not care about their individual development and is not committed to equipping them with the skill or knowledge to deliver the expected result. If this happens, the employees may develop a poor attitude towards their work and transfer their aggression to the customers. Consequently, the organization will fail to achieve its strategic objectives. This study, therefore, aims to investigate the effect of human capital development on Mutual Benefit Assurance Ltd employees' attitude towards work.

The specific research question of this study

1. To what extent does Mutual Benefits Assurance Ltd engage in human capital development?

The hypothesis generated for the study states:

Ho: There is no relationship between the benefits employees derive from Mutual Benefits Assurance Ltd and their attitude towards work.

\section{Literature Review}

In an attempt to breakdown the concept of human capital semantically, Dae-Bong (2009) states that it is a combination of "human" and "capital" with the latter referring to factors of production that are engaged in the process of creating goods and services without themselves being significantly consumed in the process of production. The former, on the other hand, takes charge of the entire economic activities which include production, consumption and transaction. Hence, according to the author, human capital refers to a production element that can generate added-value.

According to Enyekit, Amaehule and Teerah (2011), human capital is essential for the organization and rationalization of how other factors of production can contribute to the achievement of any result oriented productive goal in an industrial setting. The authors identify human capital elements as skills, knowledge, motivation and attitudes of a society or enterprise used to develop that society or enterprise to the point of achieving its objectives.

The concept of human capital development of course takes for granted that the activities and processes involved enhance the value of the people concerned. It is about providing an enabling environment for participants to maximize their potentials and contribute to the achievement of organizational goals (Erhurua, 2007). The use of the term "human capital development" presupposes that there must be stimulation of resourcefulness and productivity, enhancement of skills, and an increase in human knowledge.

Dae-Bong (2009, p.1) identifies two major methods of creating human capital. The first method involves utilizing "human as labour force in the classical economic perspective." This means that the input of labour, as in the case of other factors of production like land, financial capital and machinery, generate economic added-value. According to the author, "The other is based on the assumption that the investment of physical capital may show the same effectiveness with that of human capital on education and training" (Dae-Bong 2009, pp.1-2).

To achieve effective human capital development, the management of an organization must see the employees as assets instead of liabilities. Hence, deliberate efforts must be made to develop their potentials and create conducive environment for them to operate. One of the ways to ensure employee commitment and personal engagement is employee-employer relations.

\section{Employee-employer Relations}

Public relations is required in any organization to achieve mutual understanding, provide information and obtain reactions from parties affected by that 
organization, which in this case are employees (Amodu, 2007). According to Daramola (2003), employee relations is a specialized arm of public relations that focuses on building and maintaining better relationships between the management of an organization and the employees. Pettinger (1999, p.9) also describes it as the summary of the relationship existing between employers and their work force within and between different units or departments in organizations. Efforts of public relations begin before the hiring of an employee and continue beyond the employee's time of retirement (Basking, Aronoff and Lattimore, 1997).

Tansel and Gazioglu (2013, p.2) observe that a good employee-employer or managementemployee relationship is essential for a satisfactory performance of any organization and for the employees to see themselves as stakeholders in the organization. Empowering employees through trainings, workshops, enabling environment and twoway communication will motivate them towards the corporate goal.

Daramola (2003) explains that one of the causes of problems in the relationship between employees and management in organizations is the failure of the management to talk less and listen more. While the growth of workforce generally indicates the growth of an organization, unfortunately, it also indicates potential communication gap between the employees and the management. Amodu (2010) also observes that as constant as change is in life, so is crisis in organisations if the condition is made favourable. Inability to evolve new communication models to match organizational growth will definitely provide a favourable condition for crisis.

\section{Employee Relations and Attitude}

People hold attitudes toward many or most of the other people in their life spaces. They also tend to form attitudes in relation to tangible as well as intangible objects, causes, concepts, acts and other phenomena with which they are familiar. The holding of attitudes is clearly one of the characteristics of human beings. Much of a person's identity is definable and understandable in terms of attitudes s/he holds, how firmly the attitudes are held, and how easily changed his or her attitudes are (Pinder, 2008).

Attitudes are developed through experience but they are less stable than traits and can change as new experiences are gained or influences absorbed. Within organizations, they are affected by cultural factors (values and norms), the behavior of management (management style), policies such as those concerned with pay, recognition, promotion and the quality of working life, and the influence of the reference group (the group with whom people identify) (Armstrong, 2006).

There is no single commonly accepted definition of attitude, because different definitions and scholars view attitude from different perspectives (Olson and Zanna, as citied in Pinder, 2008, p. 254).

Attitude is a learned predisposition to respond in a favorable or unfavorable manner to a particular person, behavior, belief or theory (Feldman, as citied in Ogbebor \& Egbule, 260, p. 180). Attitudes can be defined broadly as a settled mode of thinking; they are evaluative in nature (Armstrong, 2006, p. 244). Makin et al as citied in Armstrong (2006, p. 244) say that any attitude contains an assessment of whether the object to which it refers is liked or disliked.

According to Cascio (2010, p. 46):

Attitudes are an internal state that focus on particular aspects of or objects in the environment. They include three elements: cognition, the knowledge 
an individual has about the focal object of the attitude; the emotion an individual feels toward the focal object; and an action tendency, a readiness to respond in a predetermined manner to the focal object. Job satisfaction is a multidimensional

attitude; it is made up of attitudes toward pay, promotions, co-workers, supervision, the work itself and so on. Organizational

commitment is another attitude, a bond or linking of an individual to the organization that makes it difficult to leave.

This is the definition that relates to this study because managers are interested in employees' job satisfaction and commitment principally because of the relationship between attitudes and behaviour. They assume that employees who are dissatisfied with their jobs and who are not committed strongly to their organizations will tend to be absent or late for work, to quit more often, and to place less emphasis on customer satisfaction than those whose attitudes are positive. Poor job attitudes, therefore, lead to lowered productivity and organizational productivity and organizational performance (Cascio, 2010).

Hettiararchchi and Jayarathna (2014, p.76) identify three major employee attitudes as job satisfaction, organizational commitment and job involvement. Job satisfaction implies the extent to which employees experience positive or negative feelings towards their job. It is the way they respond emotionally to the physical and social condition of their work place. Organizational commitment is the extent to which employees associate and indentify with the organization as well as their intention to maintain active participation in that organization. Job involvement is the degree to which an employee is willing to work hard in the organization even beyond normal job requirements.

Carpenter, Bauer and Erdogan (2010) consider the first two of the attitudes- job satisfaction and organizational commitmentto have the greatest potential of influencing how employees behave. According to the authors, "If the number of studies conducted on job satisfaction is an indicator, job satisfaction is probably the most important job attitude" (p.47). The authors also observe that employees who are committed to the organization are often found to use the collective pronoun "we" in opposed to "they" in reference to organizational activities.

\section{Theoretical Framework}

It is an established fact that every organization is as productive as its quality of production, labour inclusive. Then again, Walsh, Sturman, and Longstreet (2010, p.396) bring to bear the fact that human performance is the most difficult to predict. From literature, cases have shown that organizations prosper and ensure that their customers are satisfied at the expense of their employees; thus, it has been challenging to determine if a particular investment in employees could lead to specific improvements in their attitude towards work. The question then is: are organizations ready to invest or develop the capacity of their employees to meet up with the ever growing trends in the industry?

Human Capital Theory which this study is hinged upon was propounded by Theodore Schultz in 1961 and extensively developed by Gray Becker in later years. The theory suggests that education or training raises the productivity of employees by imparting useful knowledge and skills into them, bringing about positive attitudes, aptitudes, and other acquired traits that contribute to 
quality production in their work places (Becker, 1994). The theory underscores that it is expensive for organizations to provide this for their employees, however, it should be considered as an investment since the end result goes beyond personal income to a positive attitude on the part of the employee towards work ensuing in quality production for the organization. According to Becker (1994), human capital is substitutable but not transferable like other factors of production. It is, therefore, a means of production in which additional investment yields additional output. In other words, an organization gets to increase the number of its employees with certain skills, experience or knowledge that are critical to the growth of the organization and also improves the value of its workers (Eigbiremolen and Anaduaka, 2014, p.25).

Ejere (2011) observes that of all the factors of production, it is only human beings that are capable of learning, being creative, innovative, imaginative, etc. Human Capital Theory is therefore value-adding and focuses on people management, strategic investment and operational decisions that any firm could engage in at both managerial and corporate levels.

\section{Method}

The survey design was adopted for this study and the population comprised the employees of Mutual Benefits Assurance Plc. The organization was purposively selected because it has the required attributes for this study. First, it operates in a competitive sector of the Nigerian economy - the financial sector; second, several Nigerians still tend to mistrust insurance companies, which places a high demand on the employees of the organization's high level marketing skills; and finally, the employees work with targets, which requires good motivation and positive attitude to meet. The Mutual Benefits Assurance Plc Head Office at Aret Adams House, Ikorodu road, Ilupeju, Lagos was used for this study. Census was adopted to study the entire population at the head office and there were 150 employees. The data generated were, however, from 120 copies of the questionnaire that were properly filled by the respondents.

\section{Findings}

The findings of this study are presented in the tables below:

Table 1: Age and Working Experience of Respondents

\begin{tabular}{|c|c|c|c|c|c|}
\hline & & \multicolumn{4}{|c|}{$\begin{array}{l}\text { WORKING EXPERIENCE OF } \\
\text { RESPONDENTS }\end{array}$} \\
\hline & & $\begin{array}{l}\text { LESS THAN } 1 \\
\text { MONTH - } 1 \\
\text { YEAR\% }\end{array}$ & $\begin{array}{c}2-5 \\
\text { YRS \% }\end{array}$ & $\begin{array}{c}6-9 \\
\text { YRS \% }\end{array}$ & $\begin{array}{c}\text { 10- } \\
\text { ABOVE } \\
\%\end{array}$ \\
\hline \multirow[t]{5}{*}{$\begin{array}{l}\text { AGE OF } \\
\text { RESPONDENTS }\end{array}$} & $20-25$ & 48.3 & 21.2 & 16.7 & .0 \\
\hline & $26-30$ & 37.9 & 40.9 & 25.0 & .0 \\
\hline & $31-35$ & 13.8 & 27.3 & 29.2 & .0 \\
\hline & $36-40$ & .0 & 9.1 & 25.0 & 100 \\
\hline & $\begin{array}{l}41- \\
\mathrm{ABOVE}\end{array}$ & .0 & 1.5 & 4.2 & .0 \\
\hline $\begin{array}{l}\text { Total } \\
\mathbf{n}\end{array}$ & & $\begin{array}{r}100 \% \\
29\end{array}$ & $\begin{array}{r}100 \% \\
66\end{array}$ & $\begin{array}{r}100 \% \\
24\end{array}$ & $\begin{array}{r}100 \% \\
1\end{array}$ \\
\hline
\end{tabular}


Table 1 reveals the age range of the respondents and their working experience. As can be seen, ages 20 - 25 had the highest percentage among respondents that had worked in the organization for a year or less. This is not entirely surprising because at that age, youths seek job opportunities. Among the respondents who had worked in the organization for 2 to 5 years, ages 26 - 30 had the highest percentage, $40.0 \%$. The 31-35 and 36-40 age ranges had the highest percentages among the respondents that had worked in Mutual Benefits Assurance Ltd from 6-9 years, with $29.2 \%$ and $25 \%$ respectively. However, it can be generally observed that as the ages of the respondents increased, their years of experience dropped. This suggests that employees tend to leave the organization more as they grow older. This may not be unconnected to the nature of the job which requires a high level of daily mobility to follow up with clients.

Table 2: Benefits Available to Employees

\begin{tabular}{|c|c|c|c|c|}
\hline \multirow{2}{*}{$\begin{array}{c}\text { EMPLOYEES ENJOY BENEFITS } \\
\text { (Training, Workshops, health } \\
\text { insurance and allowance) }\end{array}$} & \multicolumn{4}{|c|}{ WORKING EXPERIENCE OF RESPONDENTS } \\
\hline & $\begin{array}{c}\text { LESS THAN } 1 \\
\text { MONTH - } 1 \text { YEAR } \\
\end{array}$ & 2-5 YRS & 6-9 YRS & 10- ABOVE \\
\hline STRONGLY AGREE & $17.2 \%$ & $21.2 \%$ & $25.0 \%$ & $.0 \%$ \\
\hline AGREE & $55.2 \%$ & $59.1 \%$ & $54.2 \%$ & $.0 \%$ \\
\hline UNDECIDED & $20.7 \%$ & $12.1 \%$ & $12.4 \%$ & $100.0 \%$ \\
\hline DISAGREE & $3.4 \%$ & $3.1 \%$ & $4.2 \%$ & $.0 \%$ \\
\hline STRONGLY DISAGREE & $3.5 \%$ & $4.5 \%$ & $4.2 \%$ & $.0 \%$ \\
\hline TOTAL & $\begin{array}{c}100.0 \% \\
\mathrm{n}=29\end{array}$ & $\begin{array}{c}100.0 \% \\
\mathrm{n}=66\end{array}$ & $\begin{array}{c}100.0 \% \\
\mathrm{n}=24\end{array}$ & $\begin{array}{c}100.0 \% \\
\mathrm{n}=1\end{array}$ \\
\hline
\end{tabular}

Table 2 reveals that majority of the respondents were positive that they enjoyed benefits from the organization. From the combination of the responses of those who strongly agreed and agreed, it can be seen that respondents who had worked in the organization for a year and less, 2-5 years and 6-9 years had $72.4 \%, 80.3 \%$ and $79.2 \%$ respectively. In contrast, a negligible percentage of the respondents in each category claimed they did not enjoy any benefit from the organization, and the only respondent who had worked in the organization for 10 years and above was undecided.

Table 3: Reward for Employees Outstanding Performance

\begin{tabular}{|l|c|c|c|c|}
\hline \multirow{2}{*}{$\begin{array}{c}\text { EMPLOYERS ARE } \\
\text { REWARDED FOR } \\
\text { OUTSTANDING DEEDS }\end{array}$} & \multicolumn{3}{|c|}{ WORKING EXPERIENCE OF RESPONDENTS } \\
\cline { 2 - 5 } & $\begin{array}{c}\mid \\
\text { LESS THAN 1 MONTH - } \\
\text { 1 YEAR }\end{array}$ & 2-5 YRS & 6-9 YRS & 10- ABOVE \\
\hline STRONGLY AGREE & $24.10 \%$ & $12.10 \%$ & $16.70 \%$ & $0.00 \%$ \\
\hline AGREE & $44.80 \%$ & $53.00 \%$ & $33.30 \%$ & $0.00 \%$ \\
\hline UNDECIDED & $20.70 \%$ & $28.80 \%$ & $45.80 \%$ & $100.00 \%$ \\
\hline DISAGREE & $6.90 \%$ & $4.50 \%$ & $0.00 \%$ & $0.00 \%$ \\
\hline STRONGLY DISAGREE & $3.50 \%$ & $1.60 \%$ & $4.20 \%$ & $0.00 \%$ \\
\hline \multicolumn{1}{r|}{ TOTAL } & $100.0 \%$ & $\begin{array}{c}100.0 \% \\
\mathrm{n}=66\end{array}$ & $\begin{array}{c}100.0 \% \\
\mathrm{n}=24\end{array}$ & $\begin{array}{c}100.0 \% \\
\mathrm{n}=1\end{array}$ \\
\hline
\end{tabular}


The result in Table 3 shows that most of the respondents were of the opinion that Mutual Benefits Assurance Ltd. rewarded employees for outstanding performance. This can be seen from the $68.9 \%$ positive response from those who had worked in the organization for a year and less, $65.1 \%$ from those who had worked for 2-5 years and 50\% from the 6-9 years category. The percentage of the respondents who were undecided across board is, however, worrisome. This indicates the need for the organization to be more open and clear in its approach to employee relations.

Table 4: Employees' Liberty to Offer Ideas for Productivity and Performance

\begin{tabular}{|l|c|c|c|c|}
\hline \multirow{2}{*}{$\begin{array}{c}\text { EMPLOYEES ARE } \\
\text { ALLWED TO GIVE IDEAS } \\
\text { FOR PERFORMANCE }\end{array}$} & \multicolumn{3}{|c|}{ WORKING EXPERIENCE OF RESPONDENTS } \\
\cline { 2 - 5 } & $\begin{array}{c}\text { LESS THAN 1 MONTH - } \\
\text { 1 YEAR }\end{array}$ & 2-5 YRS & 6-9 YRS & 10- ABOVE \\
\hline STRONGLY AGREE & $24.1 \%$ & $16.7 \%$ & $20.8 \%$ & $.0 \%$ \\
\hline AGREE & $58.6 \%$ & $65.2 \%$ & $54.2 \%$ & $.0 \%$ \\
\hline UNDECIDED & $13.8 \%$ & $16.7 \%$ & $20.8 \%$ & $100.0 \%$ \\
\hline DISAGREE & $3.4 \%$ & $1.5 \%$ & $.0 \%$ & $.0 \%$ \\
\hline STRONGLY DISAGREE & $.0 \%$ & $.0 \%$ & $4.2 \%$ & $.0 \%$ \\
\hline TOTAL & $100.0 \%$ & $\begin{array}{c}100.0 \% \\
\mathrm{n}=66\end{array}$ & $\begin{array}{c}100.0 \% \\
\mathrm{n}=24\end{array}$ & $\begin{array}{c}100.0 \% \\
\mathrm{n}=1\end{array}$ \\
\hline
\end{tabular}

According to Table 4, 82.7\%, 81.9\% and $75 \%$ among the respondents who had worked in the organization for a year and less, 2-5 years and 6-9 years respectively were positive that employees of Mutual Benefits Assurance Ltd were at liberty to offer ideas for productivity and performance to the management of the organization. It is logical to suggest that the organization's level of engagement of human capital development is responsible for the degree of liberty given to the employees. On the other hand, an organization that has not adequately invested in and developed the capacity of its employees may not have the same level of confidence to trust its employees' sense of judgment.

Testing Hypothesis

Ho: There is no correlation between the benefits employees derive from Mutual Benefit Assurance Ltd and their attitude towards work 


\section{Correlations}

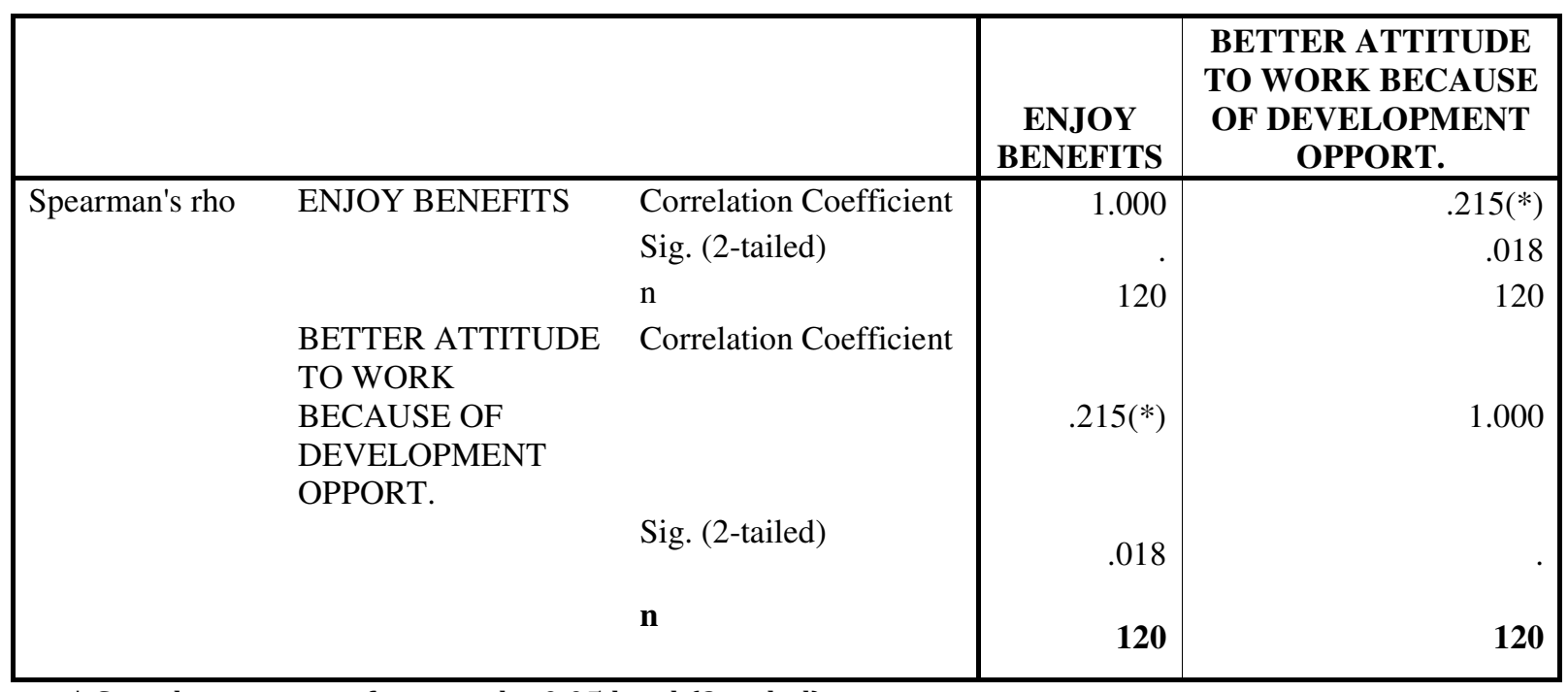

* Correlation is significant at the 0.05 level (2-tailed).

A Spearman's rank-order correlation was run to determine the relationship between the benefits enjoyed by the employees of Mutual Benefit Assurance Ltd, such as access to trainings, workshops, health insurance and allowance, and their attitude towards work. There is a strong, positive correlation between the benefits and the attitude to work, which was statistically significant $\left(\mathrm{r}_{\mathrm{s}}\right.$ $(8)=.215, p=.018)$. Consequently, the alternate hypothesis is accepted.

\section{Discussion}

This study sought to find out the extent to which Mutual Benefit Assurance Ltd engaged in human capital development and how that affected the attitude of the employees to their work. Coetzer and Rothmann (2006) observe that since the $19^{\text {th }}$ century, there had been rapid economic growth and urbanization among other things, thereby leading to intense competition and rivalry among companies. They further observe that the impact of the competition is also felt among people employed in the insurance industry because of the pressure to produce results. Lai, Chan, Ko and Boey (2000) conducted a survey among 2, 589 employees in the insurance industry and found that among their sources of stress was the tendency of dealing with difficult clients, challenges of meeting deadlines, and the constant drive to achieve targets.

The foregoing crystallizes the role of employees in bearing the burden of the competition that exists among their companies. It also necessitates constant efforts on the part of the companies to ensure the wellbeing and adequate development of the employees to achieve organizational objectives.

This current study shows that Mutual Benefit Assurance Ltd engaged in human capital development to a large extent as revealed by the employees. For instance, more than three quarters of the respondents, $77.5 \%$, claimed that they enjoyed benefits such as training, workshops, health insurance and allowance from the company. In the fast paced and dynamic insurance industry, such benefits as stated above would go a long way in retaining the loyalty of employees as well as encouraging them to face the stress identified by Lai et al (2000).

This finding contributes to the Human Capital Theory by showing that employers 
such as Mutual Benefit Assurance Ltd are aware that training employees is a worthy investment because it raises their productivity. With the majority of the respondents in this study claiming to have benefited from training and workshops, it should be expected that the organization will in turn benefit from the skills acquired by those employees.

It was also discovered that Mutual Benefit Assurance had a reward system in place that was recognised by $62.5 \%$ of the respondents. Since the company gave its employees targets periodically, it is not surprising that outstanding performances are rewarded to compensate hard work and motivate others to work harder. It is nonetheless surprising that $30.8 \%$ of the respondents were not certain if there was a reward system in place or not. While this may be because people in this category might not have benefited from such reward, it hardly excuses the organisation for not making such a valuable initiative popular among its employees.

Considering the competitiveness of businesses generally and the insurance industry specifically, companies cannot afford to restrict initiatives for productivity and performance enhancement to the management. There is a need for the employees to see themselves as stakeholders enough to offer suggestions on how to achieve greater productivity. This study reveals that $80 \%$ of the respondents were positive that they were at liberty of offer suggestions to the management on issues of productivity and performance.

Having established in this study that Mutual Benefit Assurance Ltd's human capital efforts are recognised by its employees, it becomes important to find out if such efforts by the organisation affect the attitude of employees to their work. From the Spearman's rankorder correlation test, we discover that there is in fact a strong, positive correlation between the benefits the respondents received from the company and their attitude to work. This result is significant because attitude of the employees of any organisation determines how much effort they invest into carrying out their tasks and the extent they are willing to go in meeting the needs of their clients.

\section{Conclusion}

Globalization has created a platform on which all companies can compete irrespective of their sizes and capabilities. The implication of this is that no company can lay claim to a territorial dominance merely because it is the only "such" company in the environment. Customers have been given choices that may be as physically far as the other end of the globe but as virtually close as the next click. This, therefore, necessitates increased efforts on the part of organisations to increase their competitive advantage by investing in their human capital. Good employee relations is crucial to attracting and maintaining skilled and dynamic employees that will provide satisfactory services to customers.

This study has established that Mutual Benefits Assurance Ltd., one of the leading insurance companies in Nigeria, to a large extent engaged in human capital development. We also found that the efforts of the company positively affected the attitude of the employees to their work. Nevertheless, the company needs to do more to retain its employees. As the study reveals, the years the employees spent working in the company reduced as they became older, such that only $4.2 \%$ of the respondents who were 41 years and above had worked in the company from 6 to 9 years. It was also discovered that only one of the respondents had spent 10 and above years and this was among the 36-40 age group. Considering that census was used for this study, we can generally say that employees tend to leave the company after only a few years of service. The implication of this is that no matter how effective the human capital development efforts of Mutual Benefits Assurance Ltd. is, employees still migrate to other jobs taking with them whatever benefits acquired, particularly in the area of training. This study, therefore, recommends the following: 
1. Organisations should not only focus on enhanced skill acquisition of staff, they should pay attention to the general wellbeing of the employees and put in place strategies to retain them in the organisation.

2. Organisations should put in place necessary measures to create job security particularly for older members of staff. The place of experience and skills acquired over time should be preserved. The vigour of youthful staff should be complementary to the stability offered by older staff rather than a substitution for them. One of the major claims of the Human Capital Theory is that human capital is sustainable but not transferable. Organizations should ensure as much as possible the experience and training acquired by employees over time are not lost to competitors.

\section{Acknowledgement}

We like to acknowledge Covenant University, Ota, Ogun State, Nigeria for sponsoring our participation in this conference and the publication of the paper.

\section{References}

1. Amodu, L O. (2007) 'Globalization: The Challenges of Public Relations in a Contracting World,' International Journal of Communication, 7, 175-183.

2.Amodu, L O. (2010), Public Relations: The Art and Social Science of Crisis Management, Akinfeleye, R A. (ed), Lagos, Department of Mass Communication, University of Lagos.

3. Armstrong, M. (2006) A Handbook of Human Resource Management Practice $\left(10^{\text {th }}\right.$ ed.), Kogan Books, United Kingdom.

4. Baskin, O., Aronoff, C. and Lattimore, D. (1997) Public Relations: The Profession and the Practice, McGraw-Hill Companies, Inc, New York.
5. Becker, G. (1994) Human Capital: A Theoretical and Empirical Analysis with Special Reference to Education, The University of Chicago Press, Chicago.

6. Bressler, M S. (2014) 'How Small Businesses Master the Art of Competition through Superior Competitive Advantage,' Journal of Management and Marketing Research, 11, 1-12.

7. Carpenter, M., Bauer, T. and Erdogan, B. (2010) Principles of Management, Flat World Knowledge, Inc, United State.

8. Cascio, W F. (2010). Managing Human Resources: Productivity, Quality of Work, Profits, McGraw Hill, United States.

9. Coetzer, W J. and Rothmann, S. (2006) 'Occupational Stress of Employees in an Insurance Company,' S.Afr.J.Bus.Manage, 37 (3), 29-39.

10. Dae-Bong, K. (2009) Human Capital and its Measurement. The $3^{\text {rd }}$ OECD World Forum on "Statistics, Knowledge and Policy" Charting Progress, Building Visions, Improving Life, Busan, Kora.

11. Daramola, B C. (2003) Fundamentals of Professional Public Relations. Explicit Communication Ltd, Lagos.

12. Enyekit, E O., Amaehule, S. and Teerah, L E. (2011). Achieving human capital development in Nigeria through vocational education for nation building. Proceedings of the 2011 International Conference on Teaching, Learning and Change 27-28 April 2011, Toronto, Canada, 63-69.

13. Eigbiremolen, G O. and Anaduaka, U S. (2014) 'Human Capital Development and Economic Growth: The Nigeria Experience,' International Journal of Academic Research in Business and Social Sciences, 4 (4), 25-35.

14. Ejere, S I. (2011) 'Human Capital Formation as Catalyst for National Development: Nigeria in Perspective,' 
International Business and Management, 2(2), 98-104.

15. Erluwua, H E O. (2007) 'Skills Acquisition: a Tool for Youth Empowerment for Economic Growth and Development,' Journal of business and management studies, 1(2), 116-125.

16. Gross, R. (2015) 'Human Capital Investment Theory and Theory of Reasoned Action: The Influence of Organizational Training on Employee Turnover,' International Journal of Economics, Commerce and Management, 3(2), 1-11.

17. Hettiararchchi, $H$. and Jayarathna, $S$. (2014) 'The Effect of Employee Work Related Attitudes on Employee Job Performance: a Study of Tertiary and Vocational Education Sector in Sri Lanka,' IOSR Journal of Business and Management, 16 (4), 74-83.

18. Lai, G., Chan, K B., Ko, Y C. and Boey, K W. (2000) 'Institutional Context and Stress Appraisal: the Experience of Life Insurance Agents in Singapore,' Journal of Asian \& African Studies, 35, 209-228

19. Michael E P. (1990). "The Competitive Advantage of Nations," Harvard Business Review. [Online], [Retrieved April
20, 2017], http://hbr.org/1990/03/thecompetitive-advantage-of-nations/ar/1

20. Noah, Y. and Steve, M. (2012) 'Work Environment and Job Attitude among Employees in a Nigerian Work Organization,' Journal of Sustainable Society, 1,(2), 36-43.

21. Oduyoye, O., Adebola, S. and Binuyo, A. (2013) 'Business Failure and Performance of Ogun State Cooperative Federation: an Evaluation Approach, Arabian Journal of Business and Management Review, 2 (11), 7179.

22. Ogbebor, G G., and Egbule, J F. (2006) Introduction to Psychology, Justice Jeco Press and Publishers Ltd, Benin City, Nigeria.

23. Pinder, C C. (2008) Work Motivation in Organizational Behavior (2 ${ }^{\text {nd }}$ ed.), Psychology Press, New York.

24. ansel, A. and Gazioglu, S. (2013). "Management-employee Relations, Firm Size and Job Satisfaction [Online], [Retrieved April 11 , 2016], https://ideas.repec.org/p/koc/wpaper/1307 .html 